\title{
Do blood groups have any effect on prognosis of sudden sensorineural hearing loss?
}

\section{Ani sensörinöral işitme kaybı prognozunda kan gruplarının etkisi var mıdır?}

\author{
Tolga Kırgezen (D), Nihal Seden (D), Esra Misir (D), Özgür Yiğit (iD) \\ Department of Otolaryngology, Istanbul Training and Research Hospital, Istanbul, Turkey
}

\begin{abstract}
Objectives: This study aims to investigate the effects of $\mathrm{ABO}$ blood groups on prognosis and distribution of disease in idiopathic sudden sensorineural hearing loss (ISSNHL) as a hematological and vascular parameter.
\end{abstract}

Patients and Methods: Medical records of 78 patients ( 44 males, 34 females; mean age 45.6 years; range, 14 to 80 years) treated for ISSNHL in our clinic between January 2008 and June 2019 were retrospectively analyzed. Patients were separated as $\mathrm{A}, \mathrm{B}, \mathrm{AB}$ and $\mathrm{O}$ groups regardless of their $\mathrm{Rh}$ factors. Distribution of ISSNHL was examined in the groups. Hearing gain after treatment was compared according to patients' blood groups in terms of prognosis.

Results: There were 32 group A (41\%), 13 group B (16.7\%), four group $\mathrm{AB}(5.1 \%)$ and 29 group $\mathrm{O}(37.2 \%)$ patients. No significant difference was observed when the blood group distribution of patients was compared to the local $\mathrm{ABO}$ blood group distribution in Istanbul city $(p>0.05)$. There was no significant difference between patients' age and gender distribution $(\mathrm{p}>0.05)$. The measurements of hearing thresholds at $250 \mathrm{~Hz}, 500 \mathrm{~Hz}, 1000 \mathrm{~Hz}, 2000 \mathrm{~Hz}, 4000 \mathrm{~Hz}$ and $8000 \mathrm{~Hz}$ frequencies were significantly lower after treatment $(\mathrm{p}<0.05)$; however, no significant difference was detected between the groups in terms of prognosis $(p>0.05)$. Pre- and post-treatment audiometric examination of patients did not show any significant difference in terms of hearing thresholds $(\mathrm{p}>0.05)$.

Conclusion: According to our findings, ABO blood group system does not affect the distribution and prognosis of ISSNHL. Keywords: ABO system, blood group, hearing, hearing loss, sudden sensorineural hearing loss.
$\ddot{O} Z$

Amaç: Bu çalışmada idiyopatik ani sensörinöral işitme kaybında (İASNİK) ABO kan gruplarının hematolojik ve vasküler bir parametre olarak hastalığın prognozu ve dağılımı üzerindeki etkisi araştırıldı.

Hastalar ve Yöntemler: Kliniğimizde Ocak 2008 ve Haziran 2019 tarihleri arasında İASNİK nedeniyle tedavi edilen 78 hastanın (44 erkek, 34 kadın; ort. yaş 45.6 yıl; dağılım, 14-80 yıl) tıbbi kayıtları retrospektif olarak incelendi. Hastalar Rh faktörlerine bakılmaksızın A, B, AB ve O grubu olarak ayrıldı. İdiyopatik ani sensörinöral işitme kaybının gruplardaki dağılımı incelendi. Tedavi sonrası işitme kazanımı hastaların kan gruplarına göre prognoz açısından karşılaştırıldı.

Bulgular: Otuz iki grup A (\%41), 13 grup B (\%16.7), dört grup $\mathrm{AB}(\% 5.1)$ ve 29 grup O (\%37.2) hasta vardı. Hastaların kan grubu dağılımı İstanbul ilindeki yerel ABO kan grubu dağılımı ile karşılaştırıldığında anlamlı farklılık gözlemlenmedi ( $>0.05)$. Hastaların yaş ve cinsiyet dağılımı arasında anlamlı farklılık yoktu ( $>>0.05)$. İşitme eşiklerinin $250 \mathrm{~Hz}, 500 \mathrm{~Hz}$, $1000 \mathrm{~Hz}, 2000 \mathrm{~Hz}, 4000 \mathrm{~Hz}$ ve $8000 \mathrm{~Hz}$ frekanslarındaki ölçümleri tedavi sonrasında anlamlı olarak daha düşüktü $(\mathrm{p}<0.05)$, ancak gruplar arasında prognoz açısından anlamlı farklılık saptanmadı ( $>0.05)$. Hastaların tedavi öncesi ve sonrası odyometrik muayenesi işitme eşikleri açısından anlamlı farklılık göstermedi ( $\mathrm{p}>0.05)$.

Sonuç: Bulgularımıza göre, $\mathrm{ABO}$ kan grubu sistemi İASNİK'nin dağılımını ya da prognozunu etkilememektedir.

Anahtar sözcükler: ABO sistemi, kan grubu, işitme, işitme kaybı, ani sensörinöral işitme kaybı.

Received: January 23, 2020 Accepted: February 05, 2020 Published online: February 07, 2020

Correspondence: Tolga Kırgezen, MD. İstanbul Eğitim ve Araştırma Hastanesi Kulak Burun Boğaz Kliniği, 34098 Fatih, İstanbul, Türkiye. e-mail: tolgakirgezen@gmail.com 
Sudden sensorineural hearing loss (SSNHL) is defined as a hearing loss of $30 \mathrm{~dB}$ and above, developed at three consecutive frequencies within the last three days. ${ }^{[1-5]}$ Of the cases, $85-90 \%$ are idiopathic (ISSNHL). ${ }^{[6]}$ Viral infections, vascular reasons, autoimmunity and rupture of the labyrinth membrane are suggested to be the main potential factors causing the hearing loss. ${ }^{[1,7-9]}$ The grade of hearing loss, onset time for treatment, audiometric configurations, comorbid illnesses (hypertension, diabetes mellitus, etc.) and presence of vestibular symptoms and tinnitus were indicated as factors affecting the prognosis. ${ }^{[7,10,11]}$

Genetically coded blood group antigens may be diathesis or resistance factors for certain diseases. It is a known fact that people with blood group A have a tendency for gastric carcinoma and that duodenal ulcer is frequently observed in people with blood group O. ${ }^{[12]}$ It is also suggested that people with blood group $\mathrm{O}$ are less likely to have coronary artery disease compared to those with other blood groups. ${ }^{[13]}$

There are certain studies investigating the relationship of blood groups with certain otologic diseases and it is suggested that certain blood groups have a tendency for noise induced hearing loss (NIHL).

Although there are certain articles ${ }^{[14,15]}$ investigating the risk factors for SSNHL in the literature, to our knowledge, there are no studies suggesting a relationship between a particular blood group and the disease. Therefore, in this study, we aimed to investigate the effects of $\mathrm{ABO}$ blood groups on prognosis and distribution of disease in ISSNHL as a hematological and vascular parameter.

\section{PATIENTS AND METHODS}

Medical records of 78 patients (44 males, 34 females; mean age 45.6 years; range, 14 to 80 years) treated for ISSNHL in Department of Otolaryngology, Istanbul Training and Research Hospital between January 2008 and June 2019 have been retrospectively analyzed. Patients with any previous hearing loss or history of ear surgery, otorrhea, external or middle ear diseases, head trauma and ototoxic drug usage, cases without pure tone audiogram, patients whose blood types could not

\begin{tabular}{|c|c|c|c|c|c|}
\hline \multicolumn{6}{|c|}{$\begin{array}{c}\text { Table } 1 \\
\text { Demographic and clinical parameters of patients }\end{array}$} \\
\hline & $\mathrm{n}$ & $\%$ & Mean \pm SD & Median & Min-Max \\
\hline Age (year) & & & $45.6 \pm 14.9$ & 45.0 & $18.0-80.0$ \\
\hline \multicolumn{6}{|l|}{ Gender } \\
\hline Female & 34 & 43.6 & & & \\
\hline Male & 44 & 56.4 & & & \\
\hline \multicolumn{6}{|l|}{ Side } \\
\hline Right & 42 & 53.8 & & & \\
\hline Left & 36 & 46.2 & & & \\
\hline \multicolumn{6}{|l|}{ Vertigo } \\
\hline- & 48 & 61.5 & & & \\
\hline+ & 30 & 38.5 & & & \\
\hline \multicolumn{6}{|l|}{ Tinnitus } \\
\hline- & 23 & 29.5 & & & \\
\hline+ & 55 & 70.5 & & & \\
\hline \multicolumn{6}{|c|}{ Grade of hearing loss } \\
\hline Slight & 6 & 7.7 & & & \\
\hline Moderate & 30 & 38.5 & & & \\
\hline Severe & 27 & 34.6 & & & \\
\hline Profound & 15 & 19.2 & & & \\
\hline \multicolumn{6}{|l|}{ Blood group } \\
\hline $\mathrm{O}$ & 29 & 37.2 & & & \\
\hline A & 32 & 41.0 & & & \\
\hline B & 13 & 16.7 & & & \\
\hline $\mathrm{AB}$ & 4 & 5.1 & & & \\
\hline
\end{tabular}


be determined, patients who did not admit to our clinic within three days following the hearing loss and cases with advanced systemic diseases were excluded. In all patients, pre- and post-treatment pure-tone audiometry hearing thresholds were measured at frequencies of $250 \mathrm{~Hz}, 500 \mathrm{~Hz}, 1000 \mathrm{~Hz}, 2000 \mathrm{~Hz}, 4000 \mathrm{~Hz}$ and $8000 \mathrm{~Hz}$ (AC40; Interacoustics, Middelfart, Denmark). The pure tone average (PTA) was determined by calculating the arithmetic mean of the $500 \mathrm{~Hz}$, $1000 \mathrm{~Hz}, 2000 \mathrm{~Hz}$, and $4000 \mathrm{~Hz}$ thresholds. The audiometric measures at the time of hospital admission before treatment and at least three months after the end of treatment were noted. The hearing gain for each frequency and PTA were calculated by taking the difference between the post- and pre-treatment thresholds. The severity of hearing loss was analyzed using the grading system proposed by the World Health Organization: less than $25 \mathrm{~dB}$ (normal), 25-40 dB (slight), 41-60 dB (moderate), 61-80 dB (severe), and above $80 \mathrm{~dB}$ (profound). ${ }^{[16]}$ The study protocol was approved by the Istanbul Training and Research Hospital Ethics Committee (numbered 1989 and dated September 13, 2019). A written informed consent was obtained from each patient. The study was conducted in accordance with the principles of the Declaration of Helsinki.

Systemic corticosteroids (SCs; methylprednisolone $1 \mathrm{mg} / \mathrm{kg}$ per oral and tapering gradually) were used for all patients. Only the patients who were given SC (Prednol; Mustafa Nevzat, Istanbul, Turkey) and low-molecularweight heparin (Fraxiparine, GlaxoSmithKline, Ontario, Canada) were included.

Statistical significance of the blood type distribution of patients was investigated. Blood type distribution of patients with ISSNHL was compared to local and up-todate blood type distribution in Istanbul city. Existence of vertigo and tinnitus was investigated. Pre- and posttreatment PTAs were compared. Relationship between the prognosis of ISSNHL and blood groups (the ABO system) was investigated.

\section{Statistical analysis}

In the definitive statistics of the data, average, standard deviation, median and the lowest and highest frequency and ratio values were used. Distribution of variations was measured by Kolmogorov-Smirnov test. In the analysis of quantitative independent data, Kruskal-Wallis test was used. The analysis of quantitative dependent data was performed by Wilcoxon test. In the analysis of qualitative independent data, chi-square test conditions were not maintained, and Fischer test was used. The IBM SPSS version 22.0 software (IBM Corp., Armonk, NY, USA.) was used for the analyses.

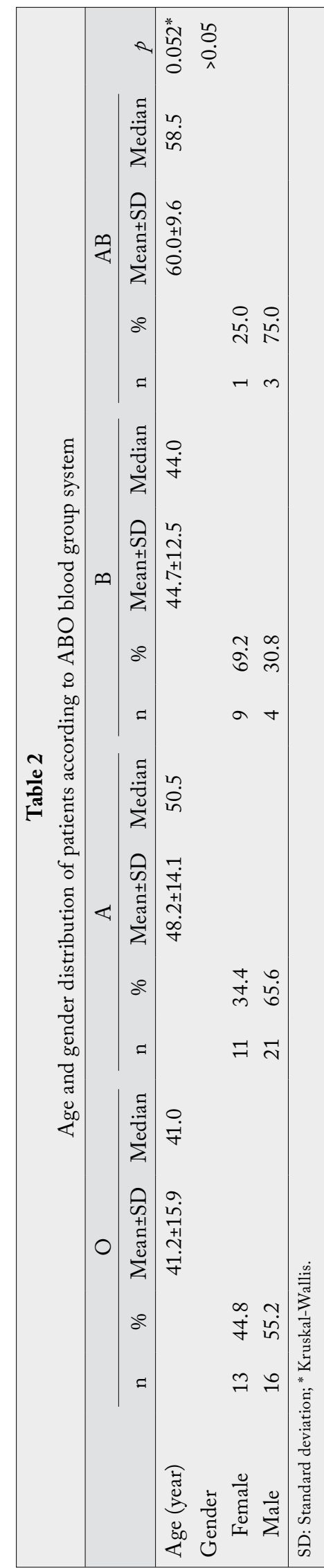




\begin{tabular}{|c|c|c|c|c|c|}
\hline \multicolumn{5}{|c|}{ Table 3} & Hearing threshold and gains of patients after treatment \\
\hline & \multicolumn{2}{|c|}{ Pre-treatment } & \multicolumn{2}{|c|}{ Post-treatment } & \multirow[b]{2}{*}{$p^{*}$} \\
\hline & Mean \pm SD & Median & Mean \pm SD & Median & \\
\hline \multicolumn{6}{|l|}{ Frequencies $(\mathrm{Hz})$} \\
\hline 250 & $68.1 \pm 23.4$ & 70.0 & $52.1 \pm 29.8$ & 50.0 & 0.000 \\
\hline 500 & $70.7 \pm 23.1$ & 75.0 & $52.2 \pm 32.2$ & 45.0 & 0.000 \\
\hline 1000 & $70.4 \pm 24.7$ & 70.0 & $51.2 \pm 32.0$ & 45.0 & 0.000 \\
\hline 2000 & $68.3 \pm 26.7$ & 67.5 & $52.0 \pm 32.3$ & 45.0 & 0.000 \\
\hline 4000 & $72.5 \pm 26.8$ & 70.0 & $58.2 \pm 33.9$ & 60.0 & 0.000 \\
\hline 8000 & $75.8 \pm 27.1$ & 77.5 & $63.6 \pm 35.0$ & 65.0 & 0.000 \\
\hline Pure tone threshold & $70.2 \pm 23.4$ & 70.0 & $52.8 \pm 30.9$ & 46.3 & 0.000 \\
\hline
\end{tabular}

\begin{tabular}{|c|c|c|c|c|c|c|c|c|c|}
\hline \multicolumn{10}{|c|}{$\begin{array}{c}\text { Table } 4 \\
\text { Comparison of hearing thresholds and gains of patients between ABO blood groups }\end{array}$} \\
\hline & \multicolumn{2}{|l|}{$\mathrm{O}$} & \multicolumn{2}{|l|}{$\mathrm{A}$} & \multicolumn{2}{|c|}{$\mathrm{B}$} & \multicolumn{2}{|c|}{$\mathrm{AB}$} & \multirow[b]{2}{*}{$p^{*}$} \\
\hline & Mean \pm SD & Median & Mean $\pm S D$ & Median & Mean \pm SD & Median & Mean $\pm S D$ & Median & \\
\hline \multicolumn{10}{|l|}{ Pure tone threshold } \\
\hline Pre-treatment & $69.1 \pm 24.1$ & 73.0 & $72.4 \pm 23.4$ & 71.0 & $64.5 \pm 20.2$ & 67.0 & $77.9 \pm 32.6$ & 81.5 & $0.761 \dagger$ \\
\hline Post-treatment & $50.2 \pm 34.8$ & 45.0 & $59.7 \pm 30.4$ & 57.1 & $38.4 \pm 18.2$ & 38.8 & $62.5 \pm 26.9$ & 55.0 & $0.153 \dagger$ \\
\hline Difference & $-18.9 \pm 22.5$ & -22.5 & $-12.8 \pm 18.2$ & -10.0 & $-26.1 \pm 21.6$ & -19.0 & $-15.4 \pm 19.4$ & -12.1 & $0.363 \dagger$ \\
\hline$p \ddagger$ & \multicolumn{2}{|c|}{0.0009} & \multicolumn{2}{|c|}{0.0019} & \multicolumn{2}{|c|}{0.0019} & \multicolumn{2}{|c|}{0.1449} & \\
\hline
\end{tabular}

\section{RESULTS}

Regardless of the $\mathrm{Rh}$ factor, patients were grouped in accordance with the $\mathrm{ABO}$ system. There were 32 group A (41\%), 13 group B (16.7\%), four group AB (5.1\%) and 29 group O (37.2\%) patients. No significant difference was observed when the blood type distribution of patients was compared to $\mathrm{ABO}$ blood type distribution in Istanbul city $(p>0.05) .{ }^{[17]}$

The age, gender, presence of vertigo and tinnitus and the severity of hearing loss of patients were given in Table 1. Age and gender distribution of patients with blood types $\mathrm{O}, \mathrm{A}, \mathrm{B}$, and $\mathrm{AB}$ were not significantly different ( $p>0.05)$ (Table 2). The measurements of hearing thresholds at $250 \mathrm{~Hz}, 500 \mathrm{~Hz}, 1000 \mathrm{~Hz}$, $2000 \mathrm{~Hz}, 4000 \mathrm{~Hz}$ and $8000 \mathrm{~Hz}$ frequencies were observed to be significantly lower after treatment $(\mathrm{p}<0.05)$ (Table 3). Pre- and post-treatment audiometric examination of patients did not show any significant difference in terms of PTAs ( $p>0.05)$ (Table 4).
Due to the fact that the ratio of $\mathrm{Rh}$-negative patients was $10 \%$, it was not possible to form homogenous patient groups. Consequently, Rh factor was not evaluated within the scope of risk and prognosis.

\section{DISCUSSION}

Despite the fact that several factors are proposed to affect the prognosis of ISSNHL, a consensus cannot be reached. In ISSNHL, some patients are affected more severely. Some individual factors for an individual patient may weaken the structure or function of the ear that would make the ear more susceptible to ISSNHL. The severity of hearing loss, unilateral or bilateral disease or frequencies involved may change for each patient due to the etiologic factors or susceptibility level of those patients.

In search of the literature, it was indicated that particular disorders have a tendency to affect patients with certain blood groups. From this point, we have examined whether blood group type was an individual prognostic factor in ISSNHL. 
It was suggested that blood type antigens were produced during the development of cochlear hairy cells in human ear, and group $\mathrm{H}$ blood antigens were detected on hairy cell membranes and stereocilia during an ultrastructural study performed on rats. Blood group antigens are thought to have a role in hairy cell development, synaptogenesis and cyclogenesis. ${ }^{[18]}$ Bener et al. ${ }^{[19]}$ indicated a positive relationship between hearing loss and $\mathrm{Rh}$-positive babies. $\mathrm{Rh}$ antigens and $\mathrm{ABO}$ blood groups may have effects on determining individual susceptibility of patients to hearing loss and its prognosis.

Moreover, Doğru et al. ${ }^{[20]}$ indicated that the development of NIHL was significantly more common in patients with blood group $\mathrm{O}$ compared to patients with other blood types. In a study conducted on 438 employees by Ayçiçek et al., ${ }^{[21]}$ it was shown that people with $\mathrm{Rh}$-positive blood type were more susceptible to NIHL compared to other blood types.

It was observed that people with different blood types developed different otoacoustic emission responses, whereas those with blood type $\mathrm{O}$ had reduced otoacoustic emission amplitude values. ${ }^{[22]}$ In another study, it was suggested that people with blood type $\mathrm{O}$ may have a higher cochlear damage risk in NIHL. ${ }^{[23]}$

Vascular pathologies and decrease of cochlear blood stream are among factors in the etiology of ISSNHL. Human blood group antigens are expressed on the surface of red blood cells and a variety of human tissues, including platelets, and vascular endothelium. ${ }^{[24]}$

Some studies in the literature reported that plasma levels of factor VIII-von Willebrand factor (vWf) complex in non-O blood group individuals were approximately $25 \%$ higher than in blood group $\mathrm{O}$ individuals. ${ }^{[25]} \mathrm{The}$ vWf plays important roles in hemostasis and thrombosis by mediating adhesion of platelets to the vascular wall, and also in platelet aggregation and development of atherosclerosis. ${ }^{[26,27]}$

Furthermore, the association between thrombosis and $\mathrm{ABO}$ blood groups was researched in the literature. It was suggested that non-O blood groups confer a higher risk of myocardial infarction, angina, peripheral vascular disease, arterial cerebral ischemia, and venous thromboembolism than group O. However, no consensus exists regarding the association's reality and magnitude, and its effects on all vascular diseases. ${ }^{[28]}$ In the studies evaluating the vascular risk of coronary heart disease (CHD), it was suggested that ABO blood group system is significantly associated with CHD risk. The blood type $\mathrm{O}$ individuals have moderately lower risk ${ }^{[13]}$ since they have reduced clotting factors in their blood. ${ }^{[29]}$
This difference among blood groups may change hematologic/vascular pathology incidence, which also plays a role in the etiology of SSNHL. Chau et al. ${ }^{[30]}$ reported that incidence of ISSNHL is $71.0 \%$. They gave the incidences of the other suspected factors as infection $(12.8 \%)$, otologic causes $(4.7 \%)$, trauma $(4.2 \%)$, vascular or hematologic factors (2.8\%), neoplasia (2.3\%), and others (2.2\%). They also suggested that establishment of a direct causal connection between these etiologic factors and SSNHL remains unclear.

Despite the fact that $\mathrm{ABO}$ antigen induced vascular changes lead to certain vascular obstructive disorders such as coronary pathologies, and that their role was indicated in otologic cases such as NIHL, they were not considered as an etiologic or prognostic factor in ISSNHL in our study. This may be due to sudden hearing loss being a multifactorial pathology. In ISSNHL, multiple etiologic factors may simultaneously play a role. The previously proven risk factors for etiology and prognosis are numerous. Constitution of a real homogenous study group is very difficult.

In this study, by looking at the possibility that blood groups may be individual sensitivity factors, we planned to investigate the role of patients' blood types according to $\mathrm{ABO}$ blood group system. We determined that $\mathrm{ABO}$ blood groups did not play a significant role in either the etiology of sudden hearing loss or the response to treatment.

Our study group was relatively small and not homogenous for distribution of $\mathrm{Rh}$ antigen. This is the limitation of our study.

In conclusion, no apparent effect of $\mathrm{ABO}$ blood groups was determined in the distribution or prognosis of ISSNHL. Studies examining $\mathrm{Rh}$ antigens with larger patient groups may be more descriptive in terms of revealing the relationship between the distribution/ prognosis of ISSNHL and the blood group antigens.

\section{Declaration of conflicting interests}

The authors declared no conflicts of interest with respect to the authorship and/or publication of this article.

\section{Funding}

The authors received no financial support for the research and/or authorship of this article.

\section{REFERENCES}

1. Psifidis AD, Psillas GK, Daniilidis JCh. Sudden sensorineural hearing loss: long-term follow-up results. Otolaryngol Head Neck Surg 2006;134:809-15. 
2. Chao TK, Chen TH. Distortion product otoacoustic emissions as a prognostic factor for idiopathic sudden sensorineural hearing loss. Audiol Neurootol 2006;11:331-8.

3. Penido Nde O, Ramos HV, Barros FA, Cruz OL, Toledo RN. Clinical, etiological and progression factors of hearing in sudden deafness. Braz J Otorhinolaryngol 2005;71:633-8.

4. Sano H, Okamoto M, Ohhashi K, Iwasaki S, Ogawa K. Quality of life reported by patients with idiopathic sudden sensorineural hearing loss. Otol Neurotol 2013;34:36-40.

5. Borton SA, Mauze E, Lieu JE. Quality of life in children with unilateral hearing loss: a pilot study. Am J Audiol 2010;19:61-72.

6. Rauch SD. Clinical practice. Idiopathic sudden sensorineural hearing loss. N Engl J Med 2008;359:833-40.

7. Enache R, Sarafoleanu C. Prognostic factors in sudden hearing loss. J Med Life 2008;1:343-7.

8. Eisenman D, Arts HA. Effectiveness of treatment for sudden sensorineural hearing loss. Arch Otolaryngol Head Neck Surg 2000;126:1161-4.

9. Kaya H, Koç AK, Sayın İ, Güneş S, Altıntaş A, Yeğin Y, et al. Vitamins A, C, and E and selenium in the treatment of idiopathic sudden sensorineural hearing loss. Eur Arch Otorhinolaryngol 2015;272:1119-25.

10. Wen YH, Chen PR, Wu HP. Prognostic factors of profound idiopathic sudden sensorineural hearing loss. Eur Arch Otorhinolaryngol 2014;271:1423-9.

11. Süslü N, Yilmaz T, Gürsel B. Utility of anti-HSP 70, TNFalpha, ESR, antinuclear antibody, and antiphospholipid antibodies in the diagnosis and treatment of sudden sensorineural hearing loss. Laryngoscope 2009;119:341-6.

12. Edgren G, Hjalgrim H, Rostgaard K, Norda R, Wikman A, Melbye $M$, et al. Risk of gastric cancer and peptic ulcers in relation to $\mathrm{ABO}$ blood type: a cohort study. Am J Epidemiol 2010;172:1280-5.

13. He M, Wolpin B, Rexrode K, Manson JE, Rimm E, Hu $\mathrm{FB}$, et al. ABO blood group and risk of coronary heart disease in two prospective cohort studies. Arterioscler Thromb Vasc Biol 2012;32:2314-20.

14. Sanyelbhaa H, Kabel A, Abo El-Naga HAE, Sanyelbhaa A, Salem H. The risk ratio for development of hereditary sensorineural hearing loss in consanguineous marriage offspring. Int J Pediatr Otorhinolaryngol 2017;101:7-10.

15. Al Khabori M. Causes of severe to profound deafness in Omani paediatric population. Int J Pediatr Otorhinolaryngol 2004;68:1307-13.
16. Hong O. Hearing loss among operating engineers in American construction industry. Int Arch Occup Environ Health 2005;78:565-74.

17. Eren C. İstanbul İlinde $A B O$ ve $\mathrm{Rh}$ kan gruplar 1 dağ1lımının analizi. Dicle Tıp Dergisi 2019;46:241-6.

18. Remezal M, Gil-Loyzaga P, Oriol R. Ultrastructural localization of $\mathrm{H}$ human-blood-group immunoreactivity rat cochlear hair cells. ORL J Otorhinolaryngol Relat Spec 1993;55:205-7.

19. Bener A, Eihakeem AA, Abdulhadi K. Is there any association between consanguinity and hearing loss. Int $\mathrm{J}$ Pediatr Otorhinolaryngol 2005;69:327-33.

20. Doğru H, Tüz M, Uygur K. Correlation between blood group and noise-induced hearing loss. Acta Otolaryngol 2003;123:941-2.

21. Ayçiçek A, Sargin R, Kenar F, Dereköy FS. Can Rh antigens be a risk factor in noise-induced hearing loss? Eur Arch Otorhinolaryngol 2009;266:363-6.

22. Chow KT, McPherson B, Fuente A. Otoacoustic emissions in young adults: Effects of blood group. Hear Res 2016;333:194-200.

23. Chen WW, Chow KT, McPherson B. ABO Blood Group and Cochlear Status: Otoacoustic Emission Markers. Ear Hear 2018;39:555-62.

24. Eastlund T. The histo-blood group ABO system and tissue transplantation. Transfusion 1998;38:975-88.

25. Gill JC, Endres-Brooks J, Bauer PJ, Marks WJ Jr, Montgomery RR. The effect of ABO blood group on the diagnosis of von Willebrand disease. Blood 1987;69:1691-5.

26. Blann AD. Plasma von Willebrand factor, thrombosis, and the endothelium: the first 30 years. Thromb Haemost 2006;95:49-55.

27. Ruggeri ZM. The role of von Willebrand factor in thrombus formation. Thromb Res 2007;120:S5-9.

28. Wu O, Bayoumi N, Vickers MA, Clark P. ABO(H) blood groups and vascular disease: a systematic review and metaanalysis. J Thromb Haemost 2008;6:62-9.

29. Koster T, Blann AD, Briët E, Vandenbroucke JP, Rosendaal FR. Role of clotting factor VIII in effect of von Willebrand factor on occurrence of deep-vein thrombosis. Lancet 1995;345:152-5.

30. Chau JK, Lin JR, Atashband S, Irvine RA, Westerberg BD. Systematic review of the evidence for the etiology of adult sudden sensorineural hearing loss. Laryngoscope 2010;120:1011-21. 